\title{
Soil Fertility Status after Harvest of Wheat (Triticum aestivum L) in Salt Affected Soils of Gujarat as Influenced by Iron and Zinc Enriched FYM
}

\author{
J.K. Malav ${ }^{1 *}$, N.N. Salvi ${ }^{2}$, R.P. Pavaya ${ }^{1}$, J.K. Patel ${ }^{1}$, \\ V.R. Patel ${ }^{1}$, B.T. Patel and J.R. Jat ${ }^{3}$ \\ ${ }^{1}$ Dept. of Agricultural Chemistry \& Soil Science, C.P. College of Agriculture, S.D. \\ Agricultural University, Sardarkrushinagar-385 506 (Gujarat), India \\ ${ }^{2}$ Agricultural Research Station, S.D. Agricultural University, Adiya, Gujarat, India \\ ${ }^{3}$ Agroforestry Research Centre, S.D. Agricultural University, Sardarkrushinagar, \\ Gujarat, India \\ *Corresponding author
}

\section{Keywords}

Wheat, Salt affected soil, Nutrient status, Enriched FYM, Iron, Zinc

Article Info

Accepted:

24 May 2019

Available Online:

10 June 2019

\section{A B S T R A C T}

The abiotic stresses, such as soil salinity and sodicity are mainly accountable for the low productivity of crops largely due to low availability of micro-nutrients especially zinc and iron. For that reason, sensible management of plant nutrients in these soils is as vital as their reclamation. A field experiment was conducted for 4 successive years, consisting of eight treatments laid out in randomized block design to evaluate the soil fertility status after harvest of wheat (Triticum aestivum $\mathrm{L}$ ) in salt affected soils of Gujarat as influenced by iron and zinc enriched FYM. The results reveal that application of recommended dose of fertilizer (120-60-00 NPK kg ha ${ }^{-1}$ ) on the basis of STV + 0.5 $\mathrm{t} \mathrm{FYM} \mathrm{ha}^{-1}$ enriched with $0.75 \mathrm{~kg} \mathrm{Zn}$ and $1.5 \mathrm{~kg}$ Fe recorded significantly higher the grain and straw yields of wheat over control. Application of recommended dose of fertilizer (120-60-00 NPK kg ha ${ }^{-1}$ ) on the basis of STV+1.0 t FYM ha ${ }^{-1}$ resulted in significantly higher organic carbon, available $\mathrm{P}_{2} \mathrm{O}_{5}$ and $\mathrm{K}_{2} \mathrm{O}$ contents in soil after harvest of wheat crop over rest of the treatments. The DTPA- extractable Fe content in soil was significantly higher with treatment $\mathrm{T}_{1}+1.5 \mathrm{~kg}$ $\mathrm{Zn} \mathrm{ha}^{-1}+3.0 \mathrm{~kg} \mathrm{Fe} \mathrm{ha}{ }^{-1}$ over control. The maximum DTPA- extractable $\mathrm{Zn}$ content was observed in the treatment which received recommended dose of fertilizer (120-60-00 NPK $\mathrm{kg} \mathrm{ha}^{-1}$ ) on the basis of STV along with $1.5 \mathrm{~kg} \mathrm{Zn} \mathrm{ha}^{-1}+3.0 \mathrm{~kg} \mathrm{Fe} \mathrm{ha}^{-1}$. Hence, the results reveal that application of FYM has a remedial effect on soil fertility along with decreasing soil salinity.

\section{Introduction}

Soil is a natural medium for plant growth and agriculture is the foundation stone of Indian economy. The urgency to increase crop production in the country has intensified the interest of soil scientists, agronomists and plant breeders in getting the better yield of crops. Since the land is limited and cannot be further increased, any technique which may result in maximum production per unit area per unit time is most welcome during the present days. Alkali soils occur most commonly, but not exclusively under arid 
climates. This is either due to presence of an excess of sodium salt or predominance of sodium among the exchangeable bases, in some cases potassium salt may be present in appreciable amount but it is of unusual occurrence. Saline and alkali soils in India occur in arid and semi-arid regions. These soils are found in U.P., Gujarat, Punjab, Haryana and Rajasthan. In India, about 6.73 M. ha are lying barren or produce very low and uneconomical yields of various crops due to excessive accumulation of salts (Sharma et al., 2004).

Salinity is one of the most crucial abiotic stresses, which inhibits crop production in arid and semi-arid areas, as those contain adequate salt in the root zone to alter the growth of crops. Besides, low precipitation is inadequate for leaching these salts below root zone levels (Zhao et al., 2007). Excessive soluble salts in the root zone inhibit plant roots from withdrawing water from neighbouring soil, practically reducing the plant available water (Bauder et al., 2001). As a result, soil salinity has capability to alter plant growth through higher concentrations of toxic ions present in the soil (Dikilitas and Karakas, 2012). Specific ion toxicities are caused by the accumulation of sodium, chloride and boron in the tissue of transpiring leaves to damaging levels. Accrual of harmful ions might hinder photosynthesis and protein synthesis; inactivate enzymes, and injure chloroplasts and other organelles (Taiz and Zeiger, 2002). These effects are more critical in older leaves, as they have been transpiring the longest, so they accrue more ions (Munns, 2002). The most influencing ions of saline soils are $\mathrm{Na}^{+}$and $\mathrm{Cl}^{-}$which affect the cell membrane by interaction, competition and selectable ion penetration and disorder on the absorption of macro and micro elements (Francisco et al., 2002). Salts damage cells of plants and inhibit their growth. The damage is because of different types of oxygen activation radicals that are toxic and activators for their cells (Jiang and Zhang, 2001). The distribution of plants, their survival and productivity are distinctly influenced by salinity (Ashraf and Harris, 2004).

These soils pose a serious problem for crop production because of their peculiar inhospitable characteristics for the plant growth. Alkali soils contain sufficient quantity of exchangeable sodium which causes the dispersion of clay and organic matter and affects physical properties, drainage, aeration and microbial activity and results in close packing of the soil particles which reduces the size and the amount of pore space and as a consequence water and air do not move through the soil readily. Modern population density makes it imperative to use salt affected soils through appropriate management and to avoid further salt damage to land. The high exchangeable sodium percentage (ESP) leads to breakdown of soil structure due to swelling and dispersion of clay particles, formation of hard crust on the soil surface which acts as a barrier for penetration of water and seedling emergence. Increase in soil $\mathrm{pH}$ reduces availability of plant nutrients like nitrogen, phosphorus, zinc, iron etc. Thus, the plant suffers from poor physical conditions, reduced nutrient availability and toxicity of certain ions.

Several organic amendment have been tried in reclamation experiments, either alone or in combination with inorganic amendments, like green manuring, FYM, rice husk, paddy straw, weeds, saw dust etc. On microbial decomposition of organic material, $\mathrm{CO}_{2}$ gas is released. The $\mathrm{CO}_{2}$ in contact with water forms carbonic acid which reacts with native $\mathrm{CaCO}_{3}$ of soil to bring calcium in solution. The increased partial pressure of $\mathrm{CO}_{2}$ and organic acid produced due to addition of organic materials mobilize $\mathrm{Ca}$ from soil minerals. The 
calcium so brought in solution under the influence of microbial decomposition from organic material releases $\mathrm{Na}^{+}$from exchange complex to reduce $\mathrm{pH}, \mathrm{SAR}$ and ESP of soil (Somani et al., 1990). The high ESP of soil increases the $\mathrm{pH}$ which decreases the availability of micronutrient like iron, copper, manganese and zinc to plants. It is established that sodicity in soil affects the growth, yield and nutrient uptake of barley to large extent (Lal and Lal, 1980).

The significance of organic matter has been proven through its effect on improving the physical conditions of soils for crop growth besides its role as fertilizers. Various organic amendments such as manure and compost have been investigated for their effectiveness of reclamation of saline sodic soils (Diez and Krauss 1997). Addition of organic amendments to soil, decrease the bulk density while increase the CEC and the water holding capacity which have diluting effect on alkali soil. Organic matter counteracts the process of sodium accumulation into the soils (Gupta et al., 1984a). The application of farmyard manure also tends to promote aggregation and helps in maintaining good physical condition of soil. Applied organic matter had a preference for divalent cations than the naturally present organic matter in soils (Poonia et al., 1980). However, Gupta et al., (1984b) cautioned against the use of organic manure in the soils undergoing sodication process because of irrigation with alkali waters. Any alkalinity build up in the presence of humic substances sharply enhanced the clay dispersion (Gupta et al., 1984b). Organic manures play a vital role in improving availability of zinc by direct contribution as well as indirectly by influencing chemical transformation reaction and microbial activity (Rathod et al., 2012). DeRemer and Smith (1964) showed that the decrease in plant-available soil $\mathrm{Zn}$ during decomposition of organic matter paralleled the decreases in the amounts of both water soluble and exchangeable soil $\mathrm{Zn}$. Organic matter and soil microbial activity are typically concentrated in the top few centimetres of soil (Murphy et al., 1998) changes in chemistry near the surface (such as increased salinity) could greatly affect soil microbial activity. Therefore, the judicious $\mathrm{Zn}$ and $\mathrm{Fe}$ management of plant nutrients in salt affected soils can enhance the food grain production potential of degraded soils. Keeping in view the above facts this study was initiated to assess soil fertility status after harvest of wheat (Triticum aestivum L) in salt affected soils of Gujarat as influenced by iron and zinc enriched FYM.

\section{Materials and Methods}

A field experiment was conducted from 201415 to 2015-16, 2016-17 and 2017-18 at Agricultural Research Station, Sardarkrushinagar Dantiwada Agricultural University, Adiya, Gujarat. This experiment consists of eight treatment combinations viz., $\mathrm{T}_{1}$ : RDF (Based on STV), $\mathrm{T}_{2}: \mathrm{T}_{1}+1.0 \mathrm{t}$ FYM $\mathrm{ha}^{-1} ; \mathrm{T}_{3}: \mathrm{T}_{1}+1.5 \mathrm{~kg} \mathrm{Zn} \mathrm{ha}{ }^{-1} ; \mathrm{T}_{4}: \mathrm{T}_{1}+3.0 \mathrm{~kg} \mathrm{Fe}$ $\mathrm{ha}^{-1} ; \mathrm{T}_{5}: \mathrm{T}_{1}+1.5 \mathrm{~kg} \mathrm{Zn} \mathrm{ha}{ }^{-1}+3.0 \mathrm{~kg} \mathrm{Fe} \mathrm{ha}^{-1}$; $\mathrm{T}_{6}: \mathrm{T}_{1}+0.5$ t FYM ha $^{-1}$ enriched with $0.75 \mathrm{~kg}$ $\mathrm{Zn} ; \mathrm{T}_{7}: \mathrm{T}_{1}+0.5$ t FYM ha $^{-1}$ enriched with 1.5 kg Fe; $\mathrm{T}_{8}: \mathrm{T}_{1}+0.5$ t FYM ha $^{-1}$ enriched with $0.75 \mathrm{~kg} \mathrm{Zn}$ and $1.5 \mathrm{~kg}$ Fe in randomized block design, which was replicated four times and wheat variety Raj-3077 was sown.

The soil of the experimental field was loamy sand in texture, alkaline in reaction and soluble salt content under unsafe limit. It was low in organic carbon, medium in available $\mathrm{P}_{2} \mathrm{O}_{5}$ and medium to high available $\mathrm{K}_{2} \mathrm{O}$ and DTPA extrable $\mathrm{Zn}$ and low status of DTPA extrable Fe (Table 2). After harvest of the crop, soil samples (post harvest soil samples) were collected and air dried in laboratory. The air dried soil samples were pounded with wooden mortar and pestle. After pounding, 
the samples were sieved through a $2 \mathrm{~mm}$ sieve and preserved in polythene bags for its chemical analysis. The procedures followed for the estimation of various parameters are given in Table 1. The data of seed and straw yield recorded from net plot and converted on hectare basis. The collected data for various parameters were statistically analyzed using Fishers' analysis of variance (ANOVA) technique and the treatments were compared at $5 \%$ level of significance.

\section{Results and Discussion}

\section{Grain and straw yield}

The vital effect of experimental variable was reflected in the final yield of wheat crop. The consequences obtainable in Table 3 make known that application of suggested quantity of fertilizer (120-60-00 NPK kg ha ${ }^{-1}$ ) on the basis of STV + 0.5 t FYM ha ${ }^{-1}$ enriched with $0.75 \mathrm{~kg} \mathrm{Zn}$ and $1.5 \mathrm{~kg} \mathrm{Fe}\left(\mathrm{T}_{8}\right)$ recorded significantly higher grain (4790 kg ha ${ }^{-1}$ ) and straw (7833 kg ha ${ }^{-1}$ ) yields of wheat over $\mathrm{T}_{1}$ (Recommended dose of fertilizer on the basis of STV only) on pooled basis. But, it was at par with $\mathrm{T}_{5}$ on pooled basis in case of grain $\left(4682 \mathrm{~kg} \mathrm{ha}^{-1}\right)$ and straw (7447 kg ha ${ }^{-1}$ ) yield. Cakmak et al., (2008) reported that there is increasing evidence showing that foliar or combined soil foliar application of $\mathrm{Zn}$ fertilizers under field conditions are highly effective and very practical way to maximize uptake and accumulation of $\mathrm{Zn}$ in whole wheat grain, raising concentration up to 60 $\mathrm{mg} \mathrm{Zn} \mathrm{kg}{ }^{-1}$. Increase in yield was due to improved availability of iron and zinc which could be attributed to the formation of stable organometalic complexes with organic matter, especially during the enrichment process to last for a longer time and release the nutrients slowly in the soil system in such a way that the nutrients are protected from fixation and made available to the plant root system throughout the crop growth (Meena et al.,
2006). This could be due to the favorite effect of adding FYM as a good source of plant nutrients. Furthermore, FYM acts as a natural soil conditioner which improved soil properties and consequently soil productivity. These results are in accordance with those obtained by More (1994).

\section{Available nutrient status after the harvest of wheat}

The data presented in Table 6,7 and 8 indicates that application of recommended dose of fertilizer (120-60-00 NPK kg ha-1) on the basis of STV +1.0 t FYM ha ${ }^{-1}\left(\mathrm{~T}_{2}\right)$ resulted in significantly higher organic carbon, available $\mathrm{P}_{2} \mathrm{O}_{5}$ and $\mathrm{K}_{2} \mathrm{O}$ contents in soil after harvest of wheat crop over rest of the treatments in all the individuals years. But in year 2016-17, organic carbon content in the soil after harvest under $\mathrm{T}_{2}$ was at par with treatments $\mathrm{T}_{3}, \mathrm{~T}_{6}, \mathrm{~T}_{7}$ and $\mathrm{T}_{8}$. While, soil $\mathrm{pH}$ was not affected by different treatments (Table 4), whereas EC of the soil after harvest of wheat crop in 2014-15 decreased significantly by $\mathrm{T} 6, \mathrm{~T}_{7} \mathrm{~T}_{8}$ treatments over $\mathrm{T}_{1}$, $\mathrm{T}_{3} \mathrm{~T}_{4}$ and $\mathrm{T}_{5}$ treatments, which did not receive FYM (Table 5). Hence, the results reveal that application of FYM has a remedial effect on soil fertility along with decreasing soil salinity (Table 5).

The use of iron and zinc enriched FYM for increasing the fertility status of soil and improving problematic salt affected soils have been in practice since long back. The iron and zinc enriched FYM in addition to its ameliorative effect is a storehouse of almost all the nutrients required for plant growth and improved soil environment via improvement in physio-chemical properties of soil. During decomposition of FYM, a series of complex reactions took place which resulted in production of acids and organic ligands of stable nature. The availability of most of the plant nutrients increased owing to reduction 
in $\mathrm{pH}$. This may also be due to the improvement in cation exchange capacity of soil and chelating effect. Thus, on addition of iron and zinc enriched FYM, the available nutrient status of soil increased considerably due to mineralization of native as well as applied nutrients through fertilizers in addition to its own nutrients content, as a matter of fact, all the available nutrients were not taken up by the crop and the rest remained in soil which improved available nutrient content of post harvest soil. The favorable conditions for microbial as well as chemical activities were due to the addition of FYM augmented mineralization of nutrients and ultimately the available nutrient status of the soil.

The significant increase in organic carbon content of soil due to application of iron and zinc enriched FYM may be attributed to mineralization of $\mathrm{N}$ by FYM in soil (Yaduvanshi, 2001). The increase in available $\mathrm{P}_{2} \mathrm{O}_{5}$ content of soil might be due to greater mobilization of native $\mathrm{P}$ by vigorous root proliferation and contribution through biomass. The buildup of available soil $\mathrm{K}_{2} \mathrm{O}$ under FYM application was the result of additional $\mathrm{K}$ supplied through it, the solubilizing action of certain organic acids produced during decomposition and its greater capacity to hold $\mathrm{K}$ in the available form (Yaduvanshi, 2001). The increase in available $\mathrm{N}, \mathrm{P}$ and $\mathrm{K}$ content of soil with the application of FYM has also been reported by More (1994), Chauhan (2001), Kumar et al., (2001), Mann et al., (2006), Yadav and Chippa (2007) and Singh et al., (2011).

\section{DTPA-extractable micronutrients}

The soil samples collected after harvest of wheat crop were analyzed for DTPAextractable micronutrients viz., $\mathrm{Fe}$ and $\mathrm{Zn}$ content in soil (Table 9 and 10). An examination of results indicates that DTPAextractable Fe content of soil after harvest of wheat varied significantly in all the individual years. The DTPA- extractable Fe content in soil was significantly higher (5.51, 5.90 and $3.90 \mathrm{mg} \mathrm{Fe} \mathrm{kg}$; except 2016-17) with treatment $\mathrm{T}_{5}\left(\mathrm{~T}_{1}+1.5 \mathrm{~kg} \mathrm{Zn} \mathrm{ha}{ }^{-1}+3.0 \mathrm{~kg} \mathrm{Fe}\right.$ $\mathrm{ha}^{-1}$ ) over control, in all the individual years. The perusal of data presented in Table 10 indicates that different treatments of $\mathrm{Zn}$ application resulted in significant increase in DTPA- extractable $\mathrm{Zn}$ content in soil after harvest. The maximum DTPA- extractable Zn content $\left(1.13,1.50,1.22\right.$ and $1.05 \mathrm{mg} \mathrm{kg}^{-1}$ soil) was observed in the treatment which received recommended dose of fertilizer (12060-00 NPK kg ha-1) on the basis of STV along with $1.5 \mathrm{~kg} \mathrm{Zn} \mathrm{ha}^{-1}+3.0 \mathrm{~kg} \mathrm{Fe} \mathrm{ha}^{-1}$ in all the individual years.

Table.1 Methods used for analysis of soil and plant sample

\begin{tabular}{|c|c|c|c|}
\hline $\begin{array}{l}\text { Sr. } \\
\text { No. }\end{array}$ & Determination & Method & Reference \\
\hline 1. & Soil Reaction $(\mathrm{pH})$ & $\begin{array}{l}\text { Potentiometery }(1: 2.5) \\
\text { Soil: water suspension }\end{array}$ & Jackson (1973) \\
\hline 2. & $\begin{array}{l}\text { Electrical } \\
\text { conductivity (EC) }\end{array}$ & $\begin{array}{l}\text { Conductometry }(1: 2.5) \\
\text { Soil: water suspension }\end{array}$ & Jackson (1973) \\
\hline 3. & Organic carbon & Walkley and Black wet oxidation method & Jackson (1973) \\
\hline 4. & Available $\mathrm{P}_{2} \mathrm{O}_{5}$ & $0.5 \mathrm{M} \mathrm{NaHCO}_{3}(\mathrm{pH} 8.5)$ & Olsen’s (1954) \\
\hline 5. & Available $\mathrm{K}_{2} \mathrm{O}$ & $\begin{array}{l}\text { Neutral } \mathrm{N} \mathrm{NH}_{4} \mathrm{OAc} \\
\text { Flame photometry method }\end{array}$ & Jackson (1973) \\
\hline 6. & $\begin{array}{l}\text { Micronutriment } \\
\text { (Fe and } \mathrm{Zn})\end{array}$ & $\begin{array}{l}\text { Atomic absorption Spectrophotometer } 0.005 \mathrm{M} \\
\text { DTPA extract ( } \mathrm{pH} 7.3)\end{array}$ & $\begin{array}{l}\text { Lindsay and Norvell } \\
\text { (1978) }\end{array}$ \\
\hline
\end{tabular}


Table.2 Physicochemical properties of the experimental soil

\begin{tabular}{|c|l|c|c|c|c|}
\hline Sr. No. & \multicolumn{4}{|c|}{ Parameters } & \multicolumn{4}{c|}{ Years } \\
\cline { 3 - 6 } & & $\mathbf{2 0 1 4 - 1 5}$ & $\mathbf{2 0 1 5 - 1 6}$ & $\mathbf{2 0 1 6 - 1 7}$ & $\mathbf{2 0 1 7 - 1 8}$ \\
\hline $\mathbf{1 .}$ & $\mathrm{pH}$ & 7.70 & 8.12 & 7.64 & 6.98 \\
\hline $\mathbf{2 .}$ & $\mathrm{EC}\left(\mathrm{dSm}^{-1}\right)$ & 1.10 & 1.18 & 1.35 & 1.45 \\
\hline $\mathbf{3 .}$ & $\mathrm{OC} \%$ & 45.31 & 0.25 & 0.38 & 0.26 \\
\hline $\mathbf{4}$. & Available $\mathrm{P}_{2} \mathrm{O}_{5}(\mathrm{~kg} / \mathrm{ha})$ & 41.25 & 43.25 & 46.58 \\
\hline $\mathbf{5 .}$ & Available $\mathrm{K}_{2} \mathrm{O}(\mathrm{kg} / \mathrm{ha})$ & 241.25 & 285.54 & 356.14 & 266.14 \\
\hline $\mathbf{6 .}$ & DTPA extractable Fe $\left(\mathrm{mg} \mathrm{kg}^{-1}\right)$ & 3.78 & 3.95 & 3.51 & 2.25 \\
\hline $\mathbf{7 .}$ & DTPA extractable $\mathrm{Zn}\left(\mathrm{mg} \mathrm{kg}^{-1}\right)$ & 0.89 & 1.08 & 0.89 & 0.76 \\
\hline & RDF Based on STV & $\mathbf{1 4 0 : 6 0 : 0}$ & $\mathbf{1 5 0 : 6 0 : 0}$ & $\mathbf{1 4 0 : 6 0 : 0}$ & $\mathbf{1 4 0 : 6 0 : 0}$ \\
\hline
\end{tabular}

Table.3 Effect of iron and zinc enriched with FYM and without enriched FYM on grain and straw yield of wheat (Pooled data 4 years)

\begin{tabular}{|c|c|c|}
\hline Treatments & $\begin{array}{c}\text { Grain yield } \\
\left(\mathrm{kg} \mathrm{ha}^{-1}\right)\end{array}$ & $\begin{array}{c}\text { Straw yield } \\
\left(\mathrm{kg} \mathrm{ha}^{-1}\right)\end{array}$ \\
\hline$T_{1}$ RDF (Based on STV) & 3781 & 6270 \\
\hline$T_{2} T_{1}+1.0$ t FYM ha ${ }^{-1}$ & 4234 & 6953 \\
\hline $\mathrm{T}_{3} \mathrm{~T}_{1}+1.5 \mathrm{~kg} \mathrm{Zn} \mathrm{ha}^{-1}$ & 4043 & 6571 \\
\hline $\mathrm{T}_{4} \mathrm{~T}_{1}+3.0 \mathrm{~kg} \mathrm{Fe} \mathrm{ha}^{-1}$ & 4189 & 6666 \\
\hline $\mathrm{T}_{5} \mathrm{~T}_{1}+1.5 \mathrm{~kg} \mathrm{Zn} \mathrm{ha}^{-1}+3.0 \mathrm{~kg} \mathrm{Fe} \mathrm{ha}^{-1}$ & 4682 & 7447 \\
\hline $\mathrm{T}_{6} \mathrm{~T}_{1}+0.5$ t FYM ha ${ }^{-1}$ En. with $0.75 \mathrm{~kg} \mathrm{Zn}$ & 4264 & 6883 \\
\hline $\mathrm{T}_{7} \mathrm{~T}_{1}+0.5 \mathrm{t}$ FYM ha ${ }^{-1}$ En. with $1.5 \mathrm{~kg} \mathrm{Fe}$ & 4516 & 7140 \\
\hline $\mathrm{T}_{8} \mathrm{~T}_{1}+0.5 \mathrm{t}$ FYM ha ${ }^{-1} \mathrm{En}$. with $0.75 \mathrm{~kg} \mathrm{Zn}$ and $1.5 \mathrm{~kg} \mathrm{Fe}$ & 4790 & 7833 \\
\hline S.Em. \pm & 94 & 153 \\
\hline C.D. at $5 \%$ & 266 & 431 \\
\hline C.V.\% & 8.75 & 8.77 \\
\hline $\mathbf{Y} \mathbf{x} \mathbf{T}$ & NS & NS \\
\hline
\end{tabular}

Table.4 Effect of iron and zinc enriched with FYM and without enriched FYM on soil pH after harvest of wheat

\begin{tabular}{|c|c|c|c|c|}
\hline \multirow[t]{2}{*}{ Treatments } & \multicolumn{4}{|c|}{ Soil pH } \\
\hline & 2014-15 & 2015-16 & 2016-17 & 2017-18 \\
\hline Initial soil value & 7.70 & 8.12 & 7.64 & 6.98 \\
\hline$T_{1}$ RDF (Based on STV) & 7.79 & 8.23 & 7.29 & 6.75 \\
\hline$T_{2} T_{1}+1.0$ t FYM ha ${ }^{-1}$ & 7.70 & 7.96 & 7.36 & 6.78 \\
\hline $\mathrm{T}_{3} \mathrm{~T}_{1}+1.5 \mathrm{~kg} \mathrm{Zn} \mathrm{ha}^{-1}$ & 7.76 & 8.00 & 7.45 & 6.86 \\
\hline $\mathrm{T}_{4} \mathrm{~T}_{1}+3.0 \mathrm{~kg} \mathrm{Fe} \mathrm{ha}^{-1}$ & 7.75 & 8.10 & 7.41 & 6.80 \\
\hline $\mathrm{T}_{5} \mathrm{~T}_{1}+1.5 \mathrm{~kg} \mathrm{Zn} \mathrm{ha}^{-1}+3.0 \mathrm{~kg} \mathrm{Fe} \mathrm{ha}^{-1}$ & 7.77 & 8.01 & 7.48 & 7.07 \\
\hline $\mathrm{T}_{6} \mathrm{~T}_{1+} 0.5 \mathrm{t} \mathrm{FYM} \mathrm{ha}^{-1}$ En. with $0.75 \mathrm{~kg} \mathrm{Zn}$ & 7.73 & 8.01 & 7.46 & 6.80 \\
\hline $\mathrm{T}_{7} \mathrm{~T}_{1+} 0.5 \mathrm{t} \mathrm{FYM} \mathrm{ha}^{-1}$ En. with $1.5 \mathrm{~kg} \mathrm{Fe}$ & 7.72 & 7.97 & 7.49 & 6.98 \\
\hline $\mathrm{T}_{8} \mathrm{~T}_{1+} 0.5 \mathrm{t} \mathrm{FYM} \mathrm{ha}^{-1} \mathrm{En}$. with $0.75 \mathrm{~kg} \mathrm{Zn}$ and $1.5 \mathrm{~kg} \mathrm{Fe}$ & 7.71 & 7.98 & 7.35 & 6.96 \\
\hline S.Em. \pm & 0.08 & 0.31 & 0.33 & 0.24 \\
\hline C.D. at $5 \%$ & NS & NS & NS & NS \\
\hline C.V.\% & 1.95 & 7.65 & 8.87 & 6.98 \\
\hline
\end{tabular}


Table.5 Effect of iron and zinc enriched with FYM

\begin{tabular}{|c|c|c|c|c|}
\hline \multirow[t]{2}{*}{ Treatments } & \multicolumn{4}{|c|}{$\operatorname{EC}\left(\mathrm{dSm}^{-1}\right)$} \\
\hline & 2014-15 & 2015-16 & 2016-17 & 2017-18 \\
\hline Initial soil value & 1.10 & 1.18 & 1.35 & 1.45 \\
\hline$T_{1}$ RDF (Based on STV) & 1.05 & 1.17 & 1.31 & 1.46 \\
\hline$T_{2} T_{1}+1.0$ t FYM ha ${ }^{-1}$ & 0.94 & 1.09 & 1.14 & 1.44 \\
\hline $\mathrm{T}_{3} \mathrm{~T}_{1}+1.5 \mathrm{~kg} \mathrm{Zn} \mathrm{ha}^{-1}$ & 1.05 & 1.15 & 1.48 & 1.56 \\
\hline $\mathrm{T}_{4} \mathrm{~T}_{1}+3.0 \mathrm{~kg} \mathrm{Fe} \mathrm{ha} \mathrm{k}^{-1}$ & 1.04 & 1.16 & 1.52 & 1.58 \\
\hline $\mathrm{T}_{5} \mathrm{~T}_{1}+1.5 \mathrm{~kg} \mathrm{Zn} \mathrm{ha}^{-1}+3.0 \mathrm{~kg} \mathrm{Fe} \mathrm{ha}^{-1}$ & 1.06 & 1.19 & 1.06 & 1.09 \\
\hline $\mathrm{T}_{6} \mathrm{~T}_{1+} 0.5 \mathrm{t} \mathrm{FYM} \mathrm{ha}^{-1}$ En. with $0.75 \mathrm{~kg} \mathrm{Zn}$ & 0.98 & 0.90 & 1.39 & 1.34 \\
\hline $\mathrm{T}_{7} \mathrm{~T}_{1+} 0.5 \mathrm{t}$ FYM ha ${ }^{-1}$ En. with $1.5 \mathrm{~kg} \mathrm{Fe}$ & 0.98 & 0.92 & 1.20 & 1.29 \\
\hline $\mathrm{T}_{8} \mathrm{~T}_{1+} 0.5 \mathrm{t} \mathrm{FYM} \mathrm{ha}{ }^{-1}$ En. with $0.75 \mathrm{~kg} \mathrm{Zn}$ and $1.5 \mathrm{~kg} \mathrm{Fe}$ & 0.98 & 0.90 & 1.33 & 1.23 \\
\hline S.Em. \pm & 0.03 & 0.04 & 0.03 & 0.05 \\
\hline C.D. at $5 \%$ & 0.08 & 0.10 & 0.09 & 0.13 \\
\hline C.V. $\%$ & 5.63 & 6.62 & 4.77 & 6.58 \\
\hline
\end{tabular}

Table.6 Effect of iron and zinc enriched with FYM and without enriched FYM on organic carbon $(\%)$ content after harvest of wheat

\begin{tabular}{|c|c|c|c|c|}
\hline \multirow[t]{2}{*}{ Treatments } & \multicolumn{4}{|c|}{ Organic carbon (\%) } \\
\hline & 2014-15 & $\begin{array}{c}2015- \\
16\end{array}$ & 2016-17 & 2017-18 \\
\hline Initial soil value & 0.31 & 0.25 & 0.38 & 0.26 \\
\hline$T_{1}$ RDF (Based on STV) & 0.18 & 0.18 & 0.31 & 0.27 \\
\hline $\mathrm{T}_{2} \mathrm{~T}_{1}+1.0 \mathrm{t}$ FYM ha ${ }^{-1}$ & 0.34 & 0.30 & 0.45 & 0.33 \\
\hline $\mathrm{T}_{3} \mathrm{~T}_{1}+1.5 \mathrm{~kg} \mathrm{Zn} \mathrm{ha}^{-1}$ & 0.17 & 0.17 & 0.39 & 0.25 \\
\hline $\mathrm{T}_{4} \mathrm{~T}_{1}+3.0 \mathrm{~kg} \mathrm{Fe} \mathrm{ha}^{-1}$ & 0.19 & 0.17 & 0.34 & 0.24 \\
\hline $\mathrm{T}_{5} \mathrm{~T}_{1}+1.5 \mathrm{~kg} \mathrm{Zn} \mathrm{ha}^{-1}+3.0 \mathrm{~kg} \mathrm{Fe} \mathrm{ha}^{-1}$ & 0.19 & 0.19 & 0.37 & 0.20 \\
\hline $\mathrm{T}_{6} \mathrm{~T}_{1+} 0.5 \mathrm{t} \mathrm{FYM} \mathrm{ha}^{-1}$ En. with $0.75 \mathrm{~kg} \mathrm{Zn}$ & 0.25 & 0.27 & 0.44 & 0.22 \\
\hline $\mathrm{T}_{7} \mathrm{~T}_{1+} 0.5$ t FYM ha ${ }^{-1}$ En. with $1.5 \mathrm{~kg} \mathrm{Fe}$ & 0.25 & 0.24 & 0.43 & 0.22 \\
\hline $\mathrm{T}_{8} \mathrm{~T}_{1+} 0.5 \mathrm{t}$ FYM ha ${ }^{-1}$ En. with $0.75 \mathrm{~kg} \mathrm{Zn}$ and $1.5 \mathrm{~kg} \mathrm{Fe}$ & 0.24 & 0.25 & 0.44 & 0.23 \\
\hline S.Em. \pm & 0.02 & 0.01 & 0.03 & 0.01 \\
\hline C.D. at $5 \%$ & 0.05 & 0.03 & 0.08 & 0.03 \\
\hline C.V.\% & 14.90 & 9.05 & 14.25 & 8.95 \\
\hline
\end{tabular}


Table.7 Effect of iron and zinc enriched with FYM and without enriched FYM on available $\mathrm{P}_{2} \mathrm{O}_{5}$ $\left(\mathrm{kg} \mathrm{ha}^{-1}\right)$ content after harvesting of wheat

\begin{tabular}{|c|c|c|c|c|}
\hline \multirow{2}{*}{ Treatments } & \multicolumn{4}{|c|}{ Available $\mathrm{P}_{2} \mathrm{O}_{5}\left(\mathrm{~kg} \mathrm{ha}^{-1}\right)$} \\
\hline & 2014-15 & 2015-16 & 2016-17 & 2017-18 \\
\hline Initial soil value & 45.87 & 41.25 & 43.25 & 46.58 \\
\hline$T_{1}$ RDF (Based on STV) & 44.30 & 38.50 & 45.10 & 42.08 \\
\hline$T_{2} T_{1}+1.0$ t FYM ha $^{-1}$ & 56.75 & 50.75 & 55.93 & 52.78 \\
\hline $\mathrm{T}_{3} \mathrm{~T}_{1}+1.5 \mathrm{~kg} \mathrm{Zn} \mathrm{ha}{ }^{-1}$ & 45.44 & 42.10 & 42.62 & 50.51 \\
\hline $\mathrm{T}_{4} \mathrm{~T}_{1}+3.0 \mathrm{~kg} \mathrm{Fe} \mathrm{ha}^{-1}$ & 44.50 & 41.33 & 42.79 & 47.11 \\
\hline $\mathrm{T}_{5} \mathrm{~T}_{1}+1.5 \mathrm{~kg} \mathrm{Zn} \mathrm{ha}^{-1}+3.0 \mathrm{~kg} \mathrm{Fe} \mathrm{ha}^{-1}$ & 44.53 & 41.10 & 43.65 & 49.57 \\
\hline $\mathrm{T}_{6} \mathrm{~T}_{1+} 0.5 \mathrm{t} \mathrm{FYM} \mathrm{ha}^{-1} \mathrm{En}$. with $0.75 \mathrm{~kg} \mathrm{Zn}$ & 53.07 & 47.23 & 42.97 & 46.82 \\
\hline $\mathrm{T}_{7} \mathrm{~T}_{1+} 0.5 \mathrm{t}$ FYM ha ${ }^{-1} \mathrm{En}$. with $1.5 \mathrm{~kg} \mathrm{Fe}$ & 55.27 & 49.58 & 53.79 & 46.24 \\
\hline $\mathrm{T}_{8} \mathrm{~T}_{1+} 0.5 \mathrm{t}$ FYM ha ${ }^{-1} \mathrm{En}$. with $0.75 \mathrm{~kg} \mathrm{Zn}$ and $1.5 \mathrm{~kg} \mathrm{Fe}$ & 52.20 & 46.92 & 52.19 & 50.55 \\
\hline S.Em. \pm & 1.67 & 1.70 & 2.93 & 2.11 \\
\hline C.D. at $5 \%$ & 4.90 & 4.99 & 8.63 & 6.21 \\
\hline C.V. \% & 6.73 & 7.59 & 12.39 & 8.76 \\
\hline
\end{tabular}

Table.8 Effect of iron and zinc enriched with FYM and without enriched FYM on available $\mathrm{K}_{2} \mathrm{O}$ $\left(\mathrm{kg} \mathrm{ha}^{-1}\right)$ content after harvesting of wheat

\begin{tabular}{|c|c|c|c|c|}
\hline \multirow[t]{2}{*}{ Treatments } & \multicolumn{4}{|c|}{ Available $\mathrm{K}_{2} \mathrm{O}\left(\mathrm{kg} \mathrm{ha}^{-1}\right)$} \\
\hline & 2014-15 & 2015-16 & 2016-17 & 2017-18 \\
\hline Initial soil value & 241.3 & 285.5 & 356.1 & 266.1 \\
\hline$T_{1}$ RDF (Based on STV) & 235.2 & 256.6 & 312.0 & 242.1 \\
\hline $\mathrm{T}_{2} \mathrm{~T}_{1}+1.0 \mathrm{t}_{\mathrm{FYM} \mathrm{ha}}{ }^{-1}$ & 253.1 & 319.1 & 421.6 & 282.3 \\
\hline $\mathrm{T}_{3} \mathrm{~T}_{1}+1.5 \mathrm{~kg} \mathrm{Zn} \mathrm{ha}{ }^{-1}$ & 245.2 & 267.5 & 375.5 & 285.5 \\
\hline $\mathrm{T}_{4} \mathrm{~T}_{1}+3.0 \mathrm{~kg} \mathrm{Fe} \mathrm{ha}{ }^{-1}$ & 231.7 & 265.3 & 381.4 & 279.3 \\
\hline $\mathrm{T}_{5} \mathrm{~T}_{1}+1.5 \mathrm{~kg} \mathrm{Zn} \mathrm{ha}^{-1}+3.0 \mathrm{~kg} \mathrm{Fe} \mathrm{ha}^{-1}$ & 241.7 & 257.7 & 355.0 & 250.8 \\
\hline $\mathrm{T}_{6} \mathrm{~T}_{1+} 0.5$ t FYM ha ${ }^{-1} \mathrm{En}$. with $0.75 \mathrm{~kg} \mathrm{Zn}$ & 246.8 & 301.5 & 387.0 & 271.7 \\
\hline $\mathrm{T}_{7} \mathrm{~T}_{1+} 0.5 \mathrm{t} \mathrm{FYM} \mathrm{ha}{ }^{-1}$ En. with $1.5 \mathrm{~kg} \mathrm{Fe}$ & 248.4 & 300.8 & 363.4 & 293.1 \\
\hline $\mathrm{T}_{8} \mathrm{~T}_{1+} 0.5 \mathrm{t}$ FYM ha ${ }^{-1} \mathrm{En}$. with $0.75 \mathrm{~kg} \mathrm{Zn}$ and $1.5 \mathrm{~kg} \mathrm{Fe}$ & 249.9 & 297.8 & 359.4 & 272.9 \\
\hline S.Em. \pm & 4.4 & 3.9 & 19.8 & 11.03 \\
\hline C.D. at $5 \%$ & 13.0 & 11.4 & 58.2 & 32.45 \\
\hline C.V. \% & 3.63 & 2.73 & 10.71 & 8.11 \\
\hline
\end{tabular}


Table.9 Effect of iron and zinc enriched with FYM and without enriched FYM on DTPA extractable $\mathrm{Fe}\left(\mathrm{mg} \mathrm{kg}^{-1}\right)$ content after harvesting of wheat

\begin{tabular}{|c|c|c|c|c|}
\hline \multirow[t]{2}{*}{ Treatments } & \multicolumn{4}{|c|}{ DTPA extractable Fe (mg kg-1) } \\
\hline & 2014-15 & $\begin{array}{c}\text { 2015- } \\
16\end{array}$ & 2016-17 & 2017-18 \\
\hline Initial soil value & 3.78 & 3.95 & 3.51 & 2.25 \\
\hline $\mathrm{T}_{1}$ RDF (Based on STV) & 3.44 & 2.61 & 2.98 & 2.25 \\
\hline$T_{2} T_{1}+1.0$ t FYM ha ${ }^{-1}$ & 4.04 & 3.44 & 3.32 & 2.55 \\
\hline $\mathrm{T}_{3} \mathrm{~T}_{1}+1.5 \mathrm{~kg} \mathrm{Zn} \mathrm{ha}^{-1}$ & 4.41 & 4.31 & 3.51 & 3.04 \\
\hline $\mathrm{T}_{4} \mathrm{~T}_{1}+3.0 \mathrm{~kg} \mathrm{Fe} \mathrm{ha}^{-1}$ & 4.66 & 5.14 & 4.00 & 3.88 \\
\hline $\mathrm{T}_{5} \mathrm{~T}_{1}+1.5 \mathrm{~kg} \mathrm{Zn} \mathrm{ha}^{-1}+3.0 \mathrm{~kg} \mathrm{Fe} \mathrm{ha}^{-1}$ & 5.51 & 5.90 & 4.28 & 3.90 \\
\hline $\mathrm{T}_{6} \mathrm{~T}_{1+} 0.5$ t FYM ha ${ }^{-1}$ En. with $0.75 \mathrm{~kg} \mathrm{Zn}$ & 3.53 & 3.45 & 2.65 & 2.37 \\
\hline $\mathrm{T}_{7} \mathrm{~T}_{1}+0.5 \mathrm{t}$ FYM ha ${ }^{-1}$ En. with $1.5 \mathrm{~kg} \mathrm{Fe}$ & 4.67 & 4.62 & 4.14 & 3.06 \\
\hline $\mathrm{T}_{8} \mathrm{~T}_{1}+0.5 \mathrm{t}$ FYM ha ${ }^{-1} \mathrm{En}$. with $0.75 \mathrm{~kg} \mathrm{Zn}$ and $1.5 \mathrm{~kg} \mathrm{Fe}$ & 4.81 & 4.75 & 4.49 & 3.78 \\
\hline S.Em. \pm & 0.25 & 0.28 & 0.24 & 0.21 \\
\hline C.D. at $5 \%$ & 0.73 & 0.82 & 0.70 & 0.62 \\
\hline C.V. \% & 11.35 & 12.98 & 13.01 & 13.54 \\
\hline
\end{tabular}

Table.10 Effect of iron and zinc enriched with FYM and without enriched FYM on DTPA extractable $\mathrm{Zn}\left(\mathrm{mg} \mathrm{kg}^{-1}\right)$ content after harvesting of wheat

\begin{tabular}{|c|c|c|c|c|}
\hline \multirow[t]{2}{*}{ Treatments } & \multicolumn{4}{|c|}{ DTPA extractable $\mathrm{Zn}\left(\mathrm{mg} \mathrm{kg}^{-1}\right)$} \\
\hline & 2014-15 & 2015-16 & 2016-17 & 2017-18 \\
\hline Initial soil value & 0.89 & 1.08 & 0.89 & 0.76 \\
\hline$T_{1}$ RDF (Based on STV) & 0.80 & 1.13 & 0.85 & 0.70 \\
\hline $\mathrm{T}_{2} \mathrm{~T}_{1}+1.0 \mathrm{t}$ FYM ha ${ }^{-1}$ & 0.76 & 1.10 & 0.83 & 0.72 \\
\hline $\mathrm{T}_{3} \mathrm{~T}_{1}+1.5 \mathrm{~kg} \mathrm{Zn} \mathrm{ha}^{-1}$ & 1.11 & 1.46 & 1.10 & 0.71 \\
\hline $\mathrm{T}_{4} \mathrm{~T}_{1}+3.0 \mathrm{~kg} \mathrm{Fe} \mathrm{ha}^{-1}$ & 0.94 & 1.09 & 1.01 & 0.77 \\
\hline$T_{5} T_{1}+1.5 \mathrm{~kg} \mathrm{Zn} \mathrm{ha}^{-1}+3.0 \mathrm{~kg} \mathrm{Fe} \mathrm{ha}^{-1}$ & 1.13 & 1.50 & 1.22 & 1.05 \\
\hline$T_{6} T_{1+} 0.5$ t FYM ha ${ }^{-1}$ En. with $0.75 \mathrm{~kg} \mathrm{Zn}$ & 1.08 & 1.30 & 1.09 & 0.79 \\
\hline $\mathrm{T}_{7} \mathrm{~T}_{1+} 0.5$ t FYM ha ${ }^{-1} \mathrm{En}$. with $1.5 \mathrm{~kg} \mathrm{Fe}$ & 0.97 & 1.21 & 0.98 & 1.00 \\
\hline $\begin{array}{l}\mathrm{T}_{8} \mathrm{~T}_{1+} 0.5 \mathrm{t} \mathrm{FYM} \mathrm{ha}{ }^{-1} \text { En. with } 0.75 \mathrm{~kg} \mathrm{Zn} \text { and } 1.5 \\
\mathrm{~kg} \mathrm{Fe}\end{array}$ & 1.06 & 1.29 & 1.12 & 1.02 \\
\hline S.Em. \pm & 0.06 & 0.06 & 0.05 & 0.06 \\
\hline C.D. at $5 \%$ & 0.17 & 0.19 & 0.13 & 0.17 \\
\hline C.V. \% & 11.65 & 10.21 & 8.87 & 13.90 \\
\hline
\end{tabular}

The increasing availability of Fe upon addition of iron and zinc enriched FYM may be attributed to (i) conversion of higher oxides of $\mathrm{Fe}\left(\mathrm{Fe}_{2} \mathrm{O}_{3}, \mathrm{Fe}_{3} \mathrm{O}_{4} \cdot \mathrm{nH}_{2} \mathrm{O}\right)$ to $\mathrm{Fe}^{++}$as a result of intensified microbial and chemical reduction (Swarup, 1989) and (ii) as a result o application of organic manure which might have resulted in formation of stable complexes with organic ligands, decreased the susceptibility of Fe to adsorption, fixation or precipitation reactions in soil and thus enhanced the availability (Swarup and 
Yaduvanshi, 2004). The application of iron and zinc enriched FYM significantly increased the DTPA-Zn might be attributed to (i) conversion of higher oxides of $\mathrm{Zn}$ to $\mathrm{Zn}^{++}$ as a result of intensified microbial and chemical reduction (ii) as a result of application of organic manure which might have resulted in formation of stable complexes with organic ligands, decreased the susceptibility of $\mathrm{Zn}$ to adsorption, fixation or precipitation reactions in soil and thus enhanced the availability. Arguments on similar lines were given by Mohanty and Rajarajan (2002).

\section{References}

Ashraf, M. and Harris, P.J.C. (2004). Potential biochemical indicators of salinity tolerance in plants. J. Plant Sci., 166: 316.

Bauder, J.W., and Brock, T.A. (2001). Irrigation and quality, soil amendment and crop effects on sodium leaching. Arid Land Res. Manage, 15: 1101-1133.

Cakmak, I., (2008). Enrichment of cereal grains with zinc: agronomic or genetic biofortification. Plant and Soil. 302(1\&2):1-17.

Chauhan, R.P.S., (2001). Integrated use of nitrogen sources in wheat grown in partially reclaimed sodic soil. Annals of Plant and Soil Research 3:17-25.

DeRemer, D.E., and Smith, R.L. (1964). A preliminary study on the nature of a $\mathrm{Zn}$ deficiency in field beans as determined by radioactive Zn. Agronomy Journal, 56: $67-70$.

Diez, T., and Krauss, M. (1997). Effect of longterm compost application on yield and soil fertility. Agro biological Research Okologie, 50: 78-84.

Dikilitas, M., and Karakas, S. (2012). Behavior of plant pathogens for crops under stress during the determination of physiological, biochemical and molecular approaches for salt stress tolerance. In Crop Production for Agricultural Improvement Heidelberg, Germany, Springer, 417-441.
Francisco, G., Jhon, L., Jifon, S., Micaela, C. and James, P. S. (2002). Gas exchange, chlorophyll and nutrient contents in relation to $\mathrm{Na}^{+}$and $\mathrm{Cl}^{-}$accumulation in sunburst mandarin grafted on different root stocks. Plant Sci., 35: 314.

Gupta, R.K., Bhumbla, D.R. and Abrol, I.P. (1984a). Effect of soil $\mathrm{pH}$, organic matter and calcium carbonate on dispersion behavior of alkali soils. Soil Science, 137: 145-251.

Gupta, R.K., Bhumbla, D.R. and Abrol, I.P. (1984b). Sodium- calcium exchange eqilibria in soils as affected by calcium carbonate and organic matter. Soil Science, 138: 109-114.

Jiang, M., and Zhang, J. (2001). Effect of abscisic acid on active oxygen species, anti oxidative defense system and oxidative damage in leaves of maize seedlings. Plant Cell Physiol., 42: 1265- 1273.

Kumar, N., Verma, L.P., Singh, R. and Prasad, K. (2001). Soil properties, nutrients uptake and productivity of rice under integrated nutrient management system. Annals of Plant and Soil research, 3: 54-57.

Lal, P. and Lal, F. (1980). A study on the evaluation of water quality with respect to boron for wheat and barley grown on loamy sand soil. Ann. Arid Zone, 19: 239241.

Mann, K.K., Brar, B.S. and Dhillon, N.S. (2006). Influence of long-term use of farmyard manure and inorganic fertilizers on nutrient availability in a Typic Ustochrept. Indian Journal of Agricultural Science, 76: 477-80.

Meena, M. C., Patel, K. P. and Rathod, D. D., 2006, Effect of $\mathrm{Zn}$ and Fe enriched FYM on mustard yield and micronutrients availability in loamy sand soil of Anand. J. Indian Soc. Soil Sci., 54: 495-499.

Mohanty, S., and Rajarajan, A. (2002). Post harvest status of macro and micronutrients in soil using organic manures in groundnut (Arachis hypogeal). Maize (Zea mays) sequence. $2^{\text {nd }}$ International Agronomy Congress, Nov.26-30, New Delhi, India, pp.92.

More, S.D., (1994). Effect of farm wastage and organic manures on soil properties, 
nutrient availability and yield of ricewheat grown on sodic vertisol. Journal of the Indian Society of Soil Science, 42: 253-256.

More, S.D., (1994). Effect of farm wastes and organic irrigated with saline water. J. Appl. Sci. Res., manure on soil properties, nutrient availability and 3(6): 431-436. Yields of rice and wheat grown on sodic Vertsoils. J. Ind. Soc. Sci., 46: 253.

Munns, R., (2002). Avenues for increasing salt tolerance of crops, and the role of physiologically based selection traits. Plant Soil, 247: 93-105.

Murphy, D.V., Sparling, G.P. and Fillery, I.R.P. (1998). Stratification of microbial biomass $\mathrm{C}$ and $\mathrm{N}$ and gross $\mathrm{N}$ mineralization with soil depth in two contrasting Western Australian agricultural soils. Australian Journal of Soil Research, 36: 45-55.

Poonia, S.R., Mehta, S.C., and Pal, R. (1980). Calcium, sodium, magnesium-sodium exchange equilibrium in relation to organic matter in soils. Proc. Intrn. Symp. Salt affected soils, 134-42.

Rathod, D.D., Meena, M.C., and Patel, K.P. 2012. Evaluation of different zinc-enriched organics as source of zinc under wheatmaize (fodder) cropping sequence on zinc- deficient typic Haplustepts. Journal of Indian Society of Soil Science, 60: 5056.

Sharma D.R. and Minhas, P.S. (2004). Soil properties and yields of upland crops as influenced by the long-term use of waters having variable residual alkalinity, salinity and sodicity. Journal of the Indian Society of Soil Science, 152: 100104.
Singh, G.P., Singh, P.L. and Panwar, A.S. (2011). Response of groundnut (Arachis hypogaea) to biofertilizers, organic and inorganic sources of nutrient in NorthEast India. Legume Research, 34: 196201.

Somani, L.L., Vyas, K.K. and Singhania, R.A. (1990). Reclamation of alkali soils through green manuring. Dryland Resources Technol., 5: 95-105.

Srikanth, K., Srinivasmurthy, C.A., Siddaramappa, R. and Ramkrishnaprama, V.R. (2000). Direct and residual effect of enriched composts, FYM, vermicompost and fertilizers on properties of an alfisol. J. Indian Soc. Soil Sci., 48: 496-499.

Swarup, A. and Yaduvanshi, N.P.S. (2004). Response of rice and wheat to organic and inorganic fertilizers and soil amendment under sodic water irrigated conditions. IRRI News Letter, 29: 49-51.

Taiz, L., and Zeiger, E. (2002). Plant Physiology, Sinauer, Sunderland, UK, 3rd edn, p. 690.

Yadav, K.K. and Chippa, B.R. (2007). Effect of FYM, gypsum and iron pyrite on fertility status of soil and yield of wheat irrigated with high RSC water. Journal of the Indian Society of Soil Science, 55: 324329.

Yaduvanshi, N.P.S., (2001). Effect of five years of rice-wheat cropping and NPK fertilizer use with and without organic and green manures on soil properties and crop yields in a reclaimed sodic soil. J. Indian Soc. Soil Sci., 49: 714-719.

Zhao, J., Ren, W., Zhi, D., Wang, L. and Xia, G. (2007). Arabidopsis DREB1A/CBF3 bestowed transgenic tall rescue increased tolerance to drought stress. Plant Cell Rep., 26: 1521-1528.

\section{How to cite this article:}

Malav, J.K., N.N. Salvi, R.P. Pavaya, J.K. Patel, V.R. Patel, B.T. Patel and Jat, J.R. 2019. Soil Fertility Status after Harvest of Wheat (Triticum aestivum L) in Salt Affected Soils of Gujarat as Influenced by Iron and Zinc Enriched FYM. Int.J.Curr.Microbiol.App.Sci. 8(06): 29492959. doi: https://doi.org/10.20546/ijcmas.2019.806.353 